and amino acid sequences of pulmonary surfactant protein SP 18 and evidence for cooperation between SP 18 and SP 28-36 in surfactant lipid adsorption. Proc Natl Acad Sci 84:66-70

33. Hawgood S, Benson BJ, Hamilton RL 1985 Effects of a surfactant-associated protein and calcium ions on the structure and surface activity of lung surfactant lipids. Biochemistry 24:184-190

34. Revak S, Merritt TA, Hallman M, Cochrane CG 1986 Reconstitution of surfactant activity using purified human apoprotein and phospholipids in vivo and in vitro. Am Rev Respir Dis 134:1258-1265

35. Yu S, Duncan W, Bhavnani B, Enhorning G, Possmayer F 1988 Effect of reconstituted pulmonary surfactant containing the 6000 -dalton hydrophobic protein on lung compliance of prematurely delivered rabbit fetuses. Pediatr Res 23:23-30

36. Tanaka Y, Takei T, Aiba T, Masuda K, Kiuchi A, Fujiwara T 1986 Development of synthetic lung surfactants. J Lipid Res $27: 475-485$

37. King RJ, Clements JA 1972 Surface active materials from dog lung. II Composition and physiological correlations. Am J Physiol 223:715-726

38. King RJ, Carmichael MC, Horowitz PM 1983 Reassembly of lipid-protein complexes of pulmonary surfactant. Proposed mechanism of interaction. J Biol Chem 258:10672-10680

39. Niewoehner DE, Rice K, Sinha AA, Wangensteen D 1987 Injurious effects of lysophosphatidylcholine on barrier properties of alveolarepithelium. J Appl Physiol 63:1979-1986

\title{
Announcements
}

\section{Meeting Announcement}

The Society for Behavioral Pediatrics will conduct its 8th Annual Scientific Meeting on September 16-17, 1990 at the Westin Hotel in Denver, CO. The theme of this meeting will be "Behavioral Pediatrics and Education: A Vital Interface." The 1990 SBP Lectureship Address will be delivered by Bettye M. Caldwell, Ph.D. For further information and registration forms, please contact Ms. Noreen Spota at (215) 248-9168.

\section{Charles E. Culpeper Foundation Scholarships in Medical Science}

The Charles E. Culpeper Foundation is currently accepting applications for its 1991 Scholarships in Medical Science Program designed to support the career development of academic physicians.

Up to three awards of $\$ 100,000$ per year for 3 y will be made to United States medical schools on behalf of candidates who are U.S. citizens, who have received their M.D. degree from a U.S. medical school in 1982 or later, and who are judged worthy of support by virtue of the quality of their research proposals. All scientific research relevant to human health is eligible for consideration. No institution may nominate more than one candidate.

In selecting awardees, emphasis will be on identifying young physicians with clear potential for making substantial contributions to science as academic physicians. Since January 1988, nine physicians have been selected as Charles E. Culpeper Foundation Medical Scholars, three each in the years 1988, 1989, and 1990.

Deadline for applications is August 15, 1990. Awards will be announced by January 15, 1991 for activation on or about July 1, 1991. Application forms and instructions may be obtained by contacting the Charles E. Culpeper Foundation at 10 Stamford Forum, Stamford, CT 06901. 